\title{
Hedonism Before Bentham
}

Ole Martin Moen ${ }^{1, *}$

How to cite: Moen, O. M. 'Hedonism Before Bentham.' Journal of Bentham Studies, 2015, 15(1): 2, pp. 1-11. DOI: https://doi.org/10.14324/111.2045-757X.007.

Published: 01 January 2015

\section{Peer Review:}

This article has been peer reviewed through the journal's standard double blind peer-review, where both the reviewers and authors are anonymised during review.

\section{Copyright:}

(C) 2015, Ole Martin Moen. This is an Open Access article distributed under the terms of the Creative Commons Attribution License (CC-BY) 3.0 https://creativecommons.org/licenses/by/3.0/, which permits unrestricted use, distribution and reproduction in any medium, provided the original author and source are credited • DOI: https://doi.org/10.14324/111.2045-757X.007

\section{Open Access:}

Journal of Bentham Studies is a peer-reviewed open access journal. 


\title{
Hedonism Before Bentham
}

\author{
OLE MARTIN MOEN \\ University of Oslo \\ o.m.moen@ifikk.uio.no
}

The hedonistic theories of Jeremy Bentham and John Stuart Mill are both widely known. Hedonism before Bentham, however, is much less known and, hitherto, no systematic presentation of hedonism's early history has been written. In this paper I seek to fill this gap in the literature by providing an overview of hedonism in early Indian and ancient Greek thought (Sections 1-4), in Roman and Medieval thought (Section 5), and from the Renaissance until the Enlightenment (Section 6).

Keywords: Aristippus, Aristotle; Hedonism; History of Ethics; Plato

\section{Early Indian and Greek Hedonism}

Where does the history of hedonism begin? The answer hinges, naturally, on how we define 'hedonism'. If we use the term in its popular sense, to mean a way of life where one seeks to promote pleasure and avoid pain, hedonism is no doubt very old, for pleasures and pains attract and repel us irrespective of our philosophical views. If we require something more, however, like philosophical reflection about value and disvalue - and the idea that pleasure and pain are the end points in such matters - the oldest example of hedonism is arguably Cārvāka, a materialist, empiricist, and hedonistic intellectual tradition in early Indian philosophy $\left(5^{\text {th }}-6^{\text {th }}\right.$ Centuries BC) from which we now only have fragments. Some of these fragments are poetical:

While life is yours, live joyously

None can escape Death's searching eye

When once this frame of ours they burn

How shall it ever again return? ${ }^{1}$

Other fragments are more practical:

By doing only what is considered practical, such as farming,

\footnotetext{
${ }^{1}$ M. Rangacarya, The Sarva-Siddharta Sangraha, Madras Government Press, Madras, 1909, p. 6.
} 
attending to cattle, trading, and doing political and administrative work, a wise man should always strive to achieve pleasure in this world. $^{2}$

In addition to the extant fragments, Cārvāka is discussed in the Vedas and the Upanishads. There its adherents are scorned for being nāstika (heretics): for challenging gods and established customs, and for giving in to this-worldly pleasures. $^{3}$

While hedonism was an undercurrent in early Indian thought, it became part of the mainstream in ancient Greece. The first hedonist among the PreSocratics was Democritus, and though we have only fragments from him left, several of these are explicitly hedonistic: 'The best thing for a man,' Democritus writes, 'will be to live his life with as much joy as possible and as little grief,' for 'joy and sorrow are the distinguishing marks of things beneficial and harmful.' Another fragment attributes to him that 'what makes life really worthwhile is not one's possessions of any externals, but one's state of mind' and that only 'fools live without enjoying life. 4

The first hedonist whose arguments we know is Aristippus of Cyrene, and though all of Aristippus' original writings have been lost, he is extensively quoted and discussed in Diogenes Laërtius' Lives of Eminent Philosophers and Xenophon's Memorabilia. According to Diogenes, Aristippus said the following about the relationship between pleasure (hédonē) and happiness (eudaimonía):

Particular pleasure is desirable for its own sake, whereas happiness is desirable not for its own sake, but for the sake of particular pleasures. That pleasure is the end is proved by the fact that from our youth up we are instinctively attracted to it, and, when we obtain it, seek nothing more, and shun nothing so much as its opposite, pain. Pleasure is good even if it proceed from the most unseemly conduct ... For even if the action be irregular, still, at any rate, the resultant pleasure is desirable for its own sake and is good. ${ }^{5}$

Aristippus was controversial, and Diogenes explains that he was accused of defending a form of Sybaritic hedonism - a hedonism that places value only on the pleasures of the moment without any regard for the future. Sybaritic hedonism derived its name from the city-state of Sybaris, where the inhabitants, according to Herodotus, caroused their way into their own demise.

\footnotetext{
${ }^{2}$ Ibid.

${ }^{3}$ Amartya Sen, The Argumentative Indian, Farrar, Straus \& Giroux, New York, 2005, p. 24.

${ }^{4}$ J. C. B. Gosling and C. C. W. Taylor, The Greeks on Pleasure, Cleardon Press, Oxford, 1982, p. 27-37. See H. Diels and W. Kranz, Die Fragmente der Vorsokratiker, 6. ed, Weidmann, Berlin, 1951, 68 A 1, §§45, 170, 188, 189, 200.

${ }^{5}$ Diogenes Laërtius, Lives of Eminent Philosophers, Loeb Classical Library, Cambridge, Mass., 1925 , II.88.
} 
Some antique texts can be interpreted in ways that support the accusation that Aristippus was indeed a Sybaritic hedonist. According to Atheneaus' Deipnosophistae, Aristippus claimed that 'past and future enjoyment had no relevance to himself, because the first no longer had being, the second had no being as yet, and was uncertain. ${ }^{6}$ Claudius Aelianus, in Varia Historia, writes that Aristippus told people 'to pay attention to each day as it comes, and similarly to that part of the day in which the individual's action or thought takes place. For he said that only the present is ours.'7 Accordingly, some interpret Aristippus as holding a very radical position: that we should be indifferent to the future and live only for the present. To make the case for such an interpretation, Terence Irwin argues that Aristippus was most likely skeptical of the idea of a lasting self. ${ }^{8}$ It is also possible to interpret Aristippus in a less radical manner, however, as holding that although pleasures have value only in the moments when they are experienced, we still have reason to be concerned with securing future pleasures and avoiding future pains. Support for such an interpretation is given claims by Aristippus such as 'the things which are productive of certain pleasures are often of a painful nature, the very opposite of pleasure" ${ }^{9}$ - which indicates that he took a diachronic perspective - and by a point he makes in the Atheneaus quote above, namely that future pleasures are 'uncertain.' If the future were irrelevant anyway, why would our level of certainty be of interest?

Aristippus was an esteemed philosopher in late $5^{\text {th }}$ Century Athens, and in Lives of Eminent Philosophers, Diogenes Laërtius gives him as elaborate a treatment as he gives Aristotle. Speusippus, who led the Academy after Plato's death, wrote a now lost dialogue titled Aristippus, and in the Phaedo (59c) Plato finds it worth noting that Aristippus was not present during the discussion. ${ }^{10}$

Aristippus founded a hedonistic school, the Cyrenaic school, which continued to exist for three generations after its founder. Its thinkers departed from some of Aristippus' ideas, but they all remained hedonists. Theodorus, who had been Aristippus' disciple, claimed, according to Diogenes, that Aristippus was right when 'he considered joy and grief to be the supreme good and evil,' but that he failed to see that the world is too brutal and unfriendly for pleasure to be achievable. ${ }^{11}$ Diogenes says of Theodorus that '[f]riendship he rejected because it did not exist between the unwise nor between the wise; with the former, when the want is removed, the friendship disappears, whereas the wise are self-sufficient, and have no need of friends." 12 Theodorus purportedly claimed that 'theft, adultery, and sacrilege would be allowable upon occasion, since none of these acts is by nature base, if once you have removed prejudice against them,' and that we should not be ashamed of indulging our passions openly, for the beautiful

\footnotetext{
${ }^{6}$ Athenaeus, The Deipnosophists, Loeb Classical Library, Cambridge, Mass.,1927, XII, 544-588.

${ }^{7}$ Claudius Aelian, Historical Miscellany, Loeb Classical Library, Cambridge, Mass.,1997, 14.6.

${ }^{8}$ Terence Irwin, 'Aristippus Against Happiness', The Monist, Vol. 74, No. 1., 1991, p. 62-6.

${ }^{9}$ Diogenes Laërtius, II. 90.

${ }^{10}$ Aristippus, we are told, was in Aegina. Diogenes Laërtius, II.65, II.72., II.5.

${ }^{11}$ Ibid. II.98.

${ }^{12}$ Ibid.
} 
exists to be enjoyed, and 'he who uses anything for the purpose for which it is useful does no wrong.' 13

Hegesias, who was also a Cyrenaic, advocated a hedonism that was less Sybaritic, but no less as dark-minded, than Theodorus'. According to Hegesias pleasure is the sole ultimate good, but it cannot be achieved, for 'the body is infected with much suffering, while the soul shares in the sufferings of the body and is a prey to disturbance, and fortune often disappoints. From all this it follows that happiness cannot be realized.' The best we can achieve is living free of pain. If this is the best, Hegesias admitted, it follows that 'life and death are each desirable in turn. ${ }^{14}$ According to Cicero, Hegesias's book Death by Starvation led to a wave of suicides and was therefore banned by king Ptolemy II Philadelphus. ${ }^{15}$ The Cyrenaic school died with Hegesias.

\section{Plato}

Plato was of the same generation as Aristippus, and in several of his dialogues, he discusses hedonism in detail. In the dialogue Protagoras, Socrates says the following:

[Y]ou put the pleasures together and the pains together, both the near and the remote, on the balance scale, and then say which of the two is more. For if you weigh pleasant things against pleasant, the greater and the more must always be taken; if painful things against painful, the fewer and the smaller. And if you weigh pleasant things against painful, and the painful is exceeded by the pleasant - whether the near by the remote or the remote by the near-you have to perform that action in which the pleasant prevails; on the other hand, if the pleasant is exceeded by the painful, you have to refrain from doing that. ${ }^{16}$

J. B. C. Gosling and C. C. W. Taylor interpret Socrates as advancing a purely hedonistic thesis: that pleasure is the sole ultimate value and pain is the sole ultimate disvalue, and that these are all that matter in practical deliberation. ${ }^{17}$ This might seem like a plausible interpretation, but it is also possible to interpret Socrates less hedonistically, as discussing how we should deliberate when only the pleasure and pain variables are taken into account. If this is the correct interpretation, Socrates needs not defend hedonism, but might defend a pluralistic theory. Support for this interpretation can be found in formulations where

\footnotetext{
${ }^{13}$ Ibid. II.99-100.

14 Ibid. II.94.

${ }^{15}$ Cicero, Tusculan Disputations, Harper \& Brothers, New York, 1888, I.34.

${ }^{16}$ Plato, Protagoras, trans. by Stanley Lombardo and Karen Bell. In Plato: Collected Works, John M. Cooper (ed.), Hackett, Indianapolis, Ind./Cambridge, Mass., 1997, 356a-c.

${ }^{17}$ Gosling and Taylor, p. 50.
} 
Socrates speaks of pleasure as 'a good' rather than 'the good' (e.g. 315e).

In the later dialogue Gorgias Socrates is decidedly less favorable in his treatment of hedonism. Socrates asks Callicles, his interlocutor, the following: 'Tell me now too whether you say that the pleasant and the good are the same or whether there is some pleasure that isn't good.' Callicles answers: 'I say they're the same. ${ }^{18}$ Socrates says that he disagrees, claims that shameful things follow from Callicles' thesis (495b), and proceeds to present a line of arguments against hedonism.

Socrates first makes Callicles agree with him that nothing can be good and bad at the same time. Thereafter, Socrates points out that when we drink, we are pained (because we are thirsty) and at the same time we are pleased (because we drink). Accordingly, drinking can be pleasurable and painful at the same time. But if something can be pleasurable and painful at the same time, yet nothing can be good and bad at the same time, then the good cannot be identical with pleasure and the bad cannot be identical with pain (496a-497d). Second, Socrates argues that even though courage is good and cowardice is bad, a courageous man may suffer and a cowardly man may enjoy - and here again, he claims, hedonists would be forced to say that he is good and bad at the same time, which is impossible (497e-499b). Socrates also argues that certain pains can be beneficial and certain pleasures can be harmful, and that the medical craft is better than the craft of pastry baking even though pastry baking is the greater source of pleasure. Finally, Socrates argues that tragedies can be good even if they are painful and that orators can be bad even if they make their audience feel good (499d-500d). After Socrates' tirade Callicles admits that he does not know how to respond.

Gosling and Taylor suggest that Socrates, in Gorgias, can be interpreted as arguing against only a shortsighted, Sybaritic hedonism, not against hedonism as such. This interpretation has some plausibility, as most of what Socrates claims can be conceded by more sophisticated hedonists than Callicles. Such an interpretation would also contribute to bringing Protagoras and Gorgias into less conflict, granted that Gosling and Taylor are right that Socrates defends hedonism in Protagoras. Gosling and Taylor's is a controversial interpretation, however, and at one point, Socrates explicitly says that he does not identify the good with pleasure (495d-e). Admittedly, it is possible to claim that this is also compatible with hedonism, for goodness can be different from pleasure but still attached to pleasure and pleasure only, but it is doubtful if Socrates would have formulated his view the way he does if he were in fact defending hedonism.

Irrespective of how we interpret Protagoras and Gorgias, Socrates argues explicitly against hedonism in the Philebus. Here Philebus and Protarchus defend hedonism, and Socrates starts out by summarizing their view in contrast to his own:

${ }^{18}$ Plato, Gorgias, trans. by Donald J. Zeyl. In Plato: Collected Works, John M. Cooper (ed.), Hackett, Indianapolis, Ind./Cambridge, Mass., 1997, 495a. 
Philebus holds that what is good for all creatures is to enjoy themselves, to be pleased and delighted, and whatever else goes together with that kind of thing. We contend that not these, but knowing, understanding, and remembering, and what belongs with them, right opinion and true calculations, are better than pleasure and more agreeable to all who can attain them. ${ }^{19}$

In addition to arguing for the value of things other than pleasure, Socrates advances two new arguments against hedonism. His first argument is that pleasures share no unifying characteristic:

If one just goes by the name, then pleasure is one single thing, but in fact it comes in many forms that are quite unlike each other. Think about it: we say that a mad man gets pleasure, and also that a sober-minded person takes pleasure in his very sobriety. Again, we say that a fool, though full of foolish opinions and hopes, gets pleasure, but likewise a wise man takes pleasure in his wisdom. But surely anyone who said in either case that these pleasures are like one another would rightly be regarded as a fool (11b-c).

If there is nothing that unites all pleasures, it is unclear how hedonists can claim that pleasure, and pleasure only, is the good. Socrates further argues that if hedonism is correct, we should prefer to be an oyster rather than a human being given that the oyster's life is just slightly more pleasant - and this, Socrates claims, is obviously wrong (21a-d).

Even though Socrates (or at least the late Socrates) was not a hedonist, he does claim, in the Republic, that the best of all lives - the philosopher's life-is also the most pleasant life. ${ }^{20}$ In fact, a philosopher's life is 729 times (!) more pleasurable than the life of an unjust tyrant (587e). Still, it is not solely by virtue of being the most pleasant life that the philosopher's life is the best; in Socrates' view, the explanation also goes the other way: It is in part by virtue of being the best life that a philosopher's life is the most pleasant.

\section{Aristotle}

Aristotle discusses hedonism at length in the Nicomachean Ethics. Early in Book VII he claims that the arguments that philosophers have advanced against hedonism so far have all failed to disprove the theory. Thereafter he argues that pleasures are ends in themselves (1153a10) and necessary parts of a good life

\footnotetext{
${ }^{19}$ Plato, Philebus, trans. by Dorothea Frede. In Plato: Collected Works, John M. Cooper (ed.), Hackett, Indianapolis, Ind./Cambridge, Mass., 1997, 11b-c.

${ }^{20}$ Plato, Republic, trans. by G.M.A. Grube and C.D.C. Reeve. In Plato: Collected Works, John M. Cooper (ed.), Hackett, Indianapolis, Ind./Cambridge, Mass., 1997, 581e-583a.
} 
(1153b18), that bodily pleasures are also good (1145a10-14), and that pleasures that do not bring with them any pains are things of which one cannot get too much (1154b16-17). None of this needs imply an endorsement of hedonism, but as Roslyn Weiss points out, Aristotle 'comes dangerously close to committing himself to the position that pleasure is indeed the supreme good. ${ }^{21}$

In Book X, however, Aristotle argues against hedonism, and he criticises the arguments for hedonism put forth by Eudoxus of Cnidus. Aristotle, who is our primary source for Eudoxus' ethics, tells us that Eudoxus held that pleasure is the good (1172b9), and goes on to discuss four arguments that Eudoxus supposedly presented in defense of his view. Eudoxus' first argument, according to Aristotle, is that

all [animals], both rational and nonrational, seek it [pleasure], and in everything, he [Eudoxus] says, what is choice worthy is good, and what is most choiceworthy is supreme. The fact that all are drawn to the same thing [i.e pleasure], indicates, in his view, that it is best for all, since each [kind of animal] finds its own good, just as it finds its own nourishment; and what is good for all, what all aim at, is the good. (1172b, 10-17)

In Aristotle's context, this is a weighty argument. Earlier in Book VII Aristotle has conceded that ' $[t]$ he fact that all, both beasts and human beings, pursue pleasure is some sign of its being in some way the best good' (1153b25-26), and famously, the Nicomachean Ethics opens with the statement that '[e]very craft and every line of inquiry, and likewise every action and decision, seems to seek some good; that is why some people were right to describe the good as what everything seeks' (1094a1-4). It is interesting to note, moreover, that Aristotle does not offer a counterargument against Eudoxus. Rather than arguing, Aristotle writes that 'These arguments of his were found credible because of his virtuous character, rather than on their own [merit]' (1172b16-19). Flattering as this might be, it is an ad hominem, and Aristotle fails to explain what is wrong with Eudoxus' first argument.

Eudoxus' second argument is an inversion of the first. Eudoxus, Aristotle explains, claims that pain is that which everyone seeks to avoid, and since pain is the opposite of pleasure, this supports the theory that pleasure is that towards which everyone strives. This is also something that Aristotle earlier has conceded - 'the contrary to that which is to be avoided, insofar as it is bad and to be avoided, is a good' (1153b3-4) — and again Aristotle does not explain what is wrong with Eudoxus' argument.

Eudoxus' third argument is that 'when pleasure is added to any other good, to just or temperate action, for instance, it makes that good more choice

${ }^{21}$ Roslyn Weiss, 'Aristotle's Criticism of Eudoxian Hedonism', Classical Philology, Vol. 74, No. 3, 1979, p. 214. 
worthy' (1172b24-26). Accordingly, pleasure must be good. Here Aristotle agrees, but he points out that this does not show that pleasure is the sole good, as hedonists suggest, for the argument is compatible with pleasure being one of several goods. Aristotle also points out that a similar argument can be used against Eudoxus' own view, for we can imagine that everything-pleasure included — can be made better if, in addition to it, we have another good, such as justice or wisdom. If this is so, then hedonism must be false, for 'nothing can be added to the good to make it more choice worthy' (1172b33-34). This is Aristotle's first substantial argument against Eudoxus.

Aristotle further argues that there are pleasures that we should not seek. $\mathrm{He}$ claims that 'pleasures are choice worthy, but not if they come from [disgraceful] sources, just as wealth is desirable, but not if you have to betray someone to get it, and health is desirable, but not if it requires you to eat anything and everything' (1173b25-27). Here Aristotle appeals to the common sense view that there are bad pleasures, and he claims that hedonism must contradict common sense in this respect. Finally Aristotle writes the following:

And no one would choose to live with a child's [level of] thought for his whole life, taking as much pleasure as possible in what pleases children, or to enjoy himself while doing some utterly shameful action, even if he would never suffer pain for it. Moreover, there are many things that we would be eager for even if they brought no pleasure, e.g. seeing, remembering, knowing, having the virtues. Even if pleasures necessarily follow from them, that does not matter, since we would choose them even if no pleasure resulted from them. It would seem clear, then, that pleasure is not the good ... (1174a1-10)

Even though it becomes clear that Aristotle rejects hedonism in the Nicomachean Ethics, it is unclear if the work achieved its full purpose: The work is written to Aristotle's son, but in spite of his father's attacks on hedonism, Diogenes Laërtius reports that 'Nicomachus, Aristotle's son, has said that he declares pleasure to be the good. ${ }^{22}$

\section{Epicurus}

Epicurus is the most central ancient hedonist, and according to Eusebius and Diogenes, Epicurus derived many of his ideas from Democritus, Aristippus, Theodorus, and Eudoxus. ${ }^{23}$ There are, however, several aspects of Epicurus' hedonism that make it original. First, Epicurus thought that ultimately, no argument is necessary to establish that pleasure is good. If we seek to argue for

\footnotetext{
${ }^{22}$ Diogenes Laërtius, VIII.87-88.

${ }^{23}$ Ibid., II.97, X.
} 
the value of pleasure by pointing, for example, to the fact that everyone strives to achieve it, we are weakening our case, for then we argue for something obvious by means of something less obvious. According to Epicurus-this is Cicero's interpretation in De Finibus - we experience the goodness of pleasure and the badness of pain as directly as we experience the warmth of fire and the sweetness of honey. ${ }^{24}$ Gosling and Taylor write that Epicurus thought that 'the experience of pleasure is experience of its goodness,' and that 'every perception involves being affected in one or other of these ways [i.e. pleasure or pain] and in such perception a sentient being grasps the value or disvalue of being so affected. ${ }^{25}$

Epicurus is sometimes dubbed a negative hedonist. A negative hedonist is one who, in some respect, holds that it is more important to avoid pain than to attain pleasure. Epicurus writes in Principal Doctrines that 'The amount of pleasure reaches its limit when all pain is removed. When pleasure is present, as long as it remains undisturbed, there is pain neither in body nor in mind. ${ }^{26}$ One possible interpretation of this is that Epicurus takes pleasure to be identical with the absence of pain. This seems puzzling, however, for a person who does not feel anything is clearly in another mental state than a person who feels pleasure. It is possible, however, to interpret Epicurus differently. On one interpretation, Epicurus claims that human psychology is such that the absence of pain is positively pleasurable. Another (and compatible) interpretation is that our primary aim in life should be to free ourselves from pains, for if we engage in strongly pleasurable activities, we will end up being pained by the negative consequences of our pursuit. We find support for such an interpretation in Epicurus' Letter to Menoeceus:

For it is not drinking bouts and continuous playing and enjoying boys and women, or consuming fish and the other dainties of an extravagant table, which produce the pleasant life, but sober calculation which searches out the reasons for every choice and avoidance and drives out the opinions which are the source of the greatest turmoil for men's souls. ${ }^{27}$

According to Epicurus the best life is a plain and simple one where one's wellbeing is not dependent on extravagant material goods:

Becoming accustomed to simple, not extravagant, ways of life makes one completely healthy, makes man unhesitant in the face of life's necessary duties, puts us in a better condition for times of extravagance which occasionally come along, and makes us

\footnotetext{
${ }^{24}$ Cicero, On Ends, Loeb Classical Library, Cambridge, Mass, 1914, I.IX.30.

${ }^{25}$ Gosling and Taylor, p. 347.

${ }^{26}$ Diogenes Laërtius, X.139.

${ }^{27}$ Ibid., 10.132
} 
fearless in the face of chance. ${ }^{28}$

Epicurus thus seems to deny neither that pleasures really exist nor that they are good; he claims, more modestly, that to get the best life possible, what we need is the right attitude. If we have the right attitude, we can, even if we are poor, live more pleasant and less painful lives than wealthy emperors. If we lack it, all the power and wealth in the world cannot help us.

Being a full-fledged hedonist, Epicurus holds that the proper aim of every human undertaking, philosophical inquiry included, is to avoid pain and, if possible, to secure pleasure. Although philosophical inquiry can hardly free us from bodily pains, other than by reminding us that they will only be temporary, it can, in Epicurus' view, free us from pains that originate in the mind. Philosophy can help us remove fears, and the fear that Epicurus takes to pain people the most - the fear of death — is a fear that, in Epicurus' view, can be demonstrated by philosophy to be groundless. First, Epicurus claims that if we take hedonism to be true, then everything good and everything bad lies in sensation, and death is the end of sensation. Death, therefore, can be neither good nor bad, and that which is neither good nor bad cannot possibly be bad. If something is not bad, moreover, we have no reason to fear it. Second, Epicurus argues that we are always outside the reach of death. The reason why is that as long as we are present, death does not exist in our lives, and when death is present, we are no longer here to suffer from it. Death, therefore, can never reach us, and we have no reason to fear that which can never reach us. ${ }^{29}$ Fear of death, which pains many people so much, can thus be removed by philosophical inquiry. Philosophy can help us live tranquil, fearless lives.

\section{Roman and Medieval Hedonism}

Epicurus' influence is vast, and a large number of Epicurean societies were founded throughout the Ancient world. Here adherents of Epicurus' philosophy gathered to live peaceful and contemplative lives, as Epicurus himself sought to do in his garden in Athens. Amafinius, Philodemus, Colotes, Hermarchus, Metrodorus of Lampsacus and Zeno of Sidon were all Epicurean hedonists, and the devout follower Diogenes of Oenoanda made a stone inscription of Epicurus' works - amounting to over 25,000 words - in the city of Oenoanda in today's Libya. Through such popularization, Epicurus' ideas reached a wide audience.

Epicurus did, however, also have a strong influence on other philosophers. Lucretius' De Rerum Natura is a poetic defense of Epicurus' philosophy, and Lucretius - acknowledging his admiration for Epicurus - wrote on the topic of his master's death that 'even Epicurus passed when his life's way came to an end, he who with his genius far exceeded everyone else, just as the sun darkens the stars

\footnotetext{
${ }^{28}$ Ibid., 10.131.

${ }^{29}$ Ibid., X.124-126.
} 
when it enters. ${ }^{30}$ In addition to defending Epicurus' views, Lucretius famously gives an additional argument for why we need not fear death. According to Lucretius, our condition after we are dead is identical with our condition before we were born, and since the time before we were born was not bad for us, then neither can the time after we die be bad.

De Rerum Natura was highly regarded by Cicero, Ovid, and Virgil, and as a result of reading Lucretius' work, Virgil was an Epicurean in his youth. Later in life, however, he abandoned hedonism, and wrote the famous Aeneid as a critical response to De Rerum Natura. ${ }^{31}$ Another criticism of hedonism can be found in Plutarch's Against Colotes, Epicurus' Disciple and Favorite, where Plutarch attacks Epicurus for holding that rather than devoting one's life to public affairs, one should withdraw from the feuds of social life and live in peace and tranquility with a group of select friends. Such a life, Plutarch argues, is not a virtuous life. Cicero presents a related criticism in De Finibus, which is a detailed discussion of the problem of what is ultimately valuable. The first two books of De Finibus deal with hedonism, and Cicero argues that no version of hedonism is compatible with human dignity. Men who fight for their country, Cicero claims, fight not because this brings them pleasure, but because of virtue, and though such fights are obviously noble, hedonism cannot account for its nobility. ${ }^{32}$

As Christianity became the dominant intellectual force in the Roman Empire, criticisms of hedonism changed. Ambrose of Milan said the following to the Christian congregation in Vercelli in 396:

it is certain then that Adam, being deceived by the desire of pleasure, fell away from the commandment of God and from the enjoyment of grace. How then can pleasure recall us to paradise, seeing that it alone deprived us of it? $?^{33}$

In addition to being theologically founded, the attacks on hedonism also became less sober. Clement of Alexandria writes in Stromateis that Epicurus advocated simple gratification of all bodily desires; St. Jerome claimed that Lucretius was mad, and that every day, he ate until he threw up. ${ }^{34}$ Arnobius wrote that if things are 'as is laid down in the doctrine of Epicurus ... it is not only a very great mistake, but shows stupid blindness, to curb innate desires, to restrict your mode of life within narrow limits, not yield to your inclinations, and do what your

\footnotetext{
${ }^{30}$ Lucretius, On the Nature of Things, Loeb Classical Library/Harvard University Press, Cambridge, Mass., 1924, 3.1042-1044

${ }^{31}$ Stephen Greenblatt, The Swerve: How the World Became Modern, Norton, New York, 2011, p. $51-52$.

${ }^{32}$ Cicero, I.IX.

${ }^{33}$ Ambrose of Milan, 'Letter to Theodosius (LXIII)', Letters, James Parker \& Co, Oxford , 1881, p. 356.

${ }^{34}$ Clement of Alexandria, 'Miscellanies'. In John Ferguson, Clement of Alexandria, Twayne Publishers, Nww York, 1974, ii, p. 21; Greenblatt, p. 53 -54; 76.
} 
passions have demanded and urged... ${ }^{35}$ The smearing of Epicurus is striking, and as Howard Jones writes, the Epicureans were accused of 'swinish gluttony, drunkenness, fornication, adultery, homosexuality, sodomy, incest - Theophilus, Clement, Pseudo-Clement, Ambrose, Epiphanius, Peter Chrysologus, Filastrius, and Augustine each contributing a little to the list. ${ }^{36}$

It is worth noting, however, that Augustine had a more interesting view on Epicurean hedonism than do the rest of the church fathers. In his Confessions, Augustine writes:

And I discussed with my friends, Alypius and Nebridius, the nature of good and evil, maintaining that, in my judgment, Epicurus would have carried off the palm [i.e. been right] if I had not believed what Epicurus would not believe: that after death there remains a life for the soul, and places of recompense. And I demanded of them: 'Suppose we are immortal and live in the enjoyment of perpetual bodily pleasure, and that without any fear of losing it—why, then, should we not be happy, or why should we search for anything else? ${ }^{37}$

In a letter to archbishop Nectarius of Constantinople he writes:

[contrary to the] opinion of the Epicureans ... the soul is not annihilated, but removes from its tenement, and continues in existence for a state of blessedness or misery, according to that which a man's actions, whether good or bad, claim as their due recompense. $^{38}$

The reason this is interesting is that it hardly contradicts hedonism. First, Augustine concedes that if there is no god who punishes us in the afterlife, hedonism is correct. Here Augustine and Epicurus agree. Second, Augustine claims that depending on how we act in this life, we will get a blessed or a miserable afterlife. This, at least on one interpretation, is as much a reaffirmation as it is a denial of hedonism, for the difference between Augustine and Epicurus appears not to be their ethical views, but their views on what happens when we die. If Epicurus had been convinced that such horrors as eternal hellfire await us after death, we have little reason to believe that he would take issue with Augustine's recommendations. If it is the suffering of hell we should act to avoid, and the joys of heaven we should act to secure, this is hedonism as good as any.

\footnotetext{
${ }^{35}$ Arnobius, Adversus Nationes, The Latin Library, URL = <http://www.thelatinlibrary.com/arnobius.html> [April 28, 2012], II.30.

${ }^{36}$ Howard Jones, The Epicurean Tradition, Routledge, Florence, Kent., 1992, p. 102.

${ }^{37}$ Augustine, City of God, Penguin Classics, London, 1984, Book 6, chapter VII, p. 11.

${ }^{38}$ Augustine, Select Letters, Loeb Classical Library/Harvard University Press, Cambridge, Mass., 1989, Letter 104.3.
} 
Hedonism was not discussed extensively after Augustine, and when Justinian forced the philosophical schools of Athens to close in 529 AD, he closed Epicurus' school after more than 700 years of continual activity. Thomas Aquinas does not seem to have been familiar with Epicurus, and does not discuss him in Summa Theologiae. He does, however, discuss Aristotle's treatment of pleasure in Nicomachean Ethics, and concludes that pleasures can be good, but that they gain their goodness, not simply by virtue of being pleasures, but by virtue of indicating that one acts in a way that realises one's nature. ${ }^{39}$ Dante, on the other hand, was aware of Epicurus, and his treatment of Epicurus in the Divine Comedy was harsh: While he placed Socrates, Plato, and Aristotle in the outer circle of Hell, in Limbo, he placed Epicurus in a burning tomb in the sixth circle. ${ }^{40}$

\section{Renaissance and Early Modern Hedonism}

As the Middle Ages came to an end, hedonistic ideas became subject to more scholarly attention. In 1400 Francisco Zabarella published De Felicitate, in which he discusses Epicurus' hedonism. Although Zabarella criticises Epicurus for holding that pleasure is the supreme good, he praises him for putting more emphasis on mental than bodily pleasures. ${ }^{41}$ Poggio Bracciolini, who was one of the major collectors of Greek and Latin manuscripts, rediscovered and published Lucretius' De Rerum Natura in 1471. Initially, Poggio is said to have been persuaded by Lucretius' hedonism, but he came to abandon these ideas later on. Fourteen years after the rediscovery of De Rerum Natura, Lorenzo Valla wrote De Voluptate (On Pleasure), where he let the spokesman 'Vegio' defend Epicurean hedonism. Since Valla laid out the view convincingly, Poggio accused him of being a hedonist - at the time, a very serious accusation. In 1473 Cicero's De Finibus, which contains a detailed discussion of hedonism, was rediscovered, and in 1533 Epicurus' letter to Menoeceus was published. With the invention of the printing press, these works were quickly spread, and they were widely read. Michel de Montaigne's Essays contains more than one hundred quotes from De Rerum Natura. ${ }^{42}$

Hedonism remained unpopular, however, especially among theologians. Philip Melanchton, in Philosophiae Moralis Epitomes, agreed with Poggio that Valla was probably guilty of being a hedonist. Martin Luther, in the tradition of the Church Fathers, interpreted Epicurus as advocating surrender to all bodily lusts, and used 'Epicureanism' repeatedly as a derogatory term. ${ }^{43}$ In his famous letter exchange with Erasmus, Luther accuses Erasmus of giving in to 'Epicurus'

\footnotetext{
${ }^{39}$ Thomas Aquinas, Summa Theologiae, Vol. 20, Cambridge University Press, Cambirdge, Question 34, Articles I-II, p. 65-70.

${ }^{40}$ Dante Alighieri, The Divine Comedy, Penguin Classics, London, 2002, 10.13-14.

${ }^{41}$ Jones, p. 144.

${ }^{42}$ Greenblatt, p. 221-249.

${ }^{43}$ Jones, p. 162-3.
} 
drunkenness. ${ }^{44}$ More interesting than Luther's misrepresentation of Epicurus' views is the way Erasmus responds. Erasmus responds, in the dialogue 'Epicurus', not by denying that he has hedonistic sympathies, but by presenting Epicurean hedonism as more enlightened and wise than Luther had assumed. One of the characters in the dialogue, named 'Hedonius', analyzes Epicurus' theory and explains that Epicurus does not advocate 'shameless love, unlawful lust,' for this brings only 'the ague, the headache, the grips, dullness of wit, disgrace, forgetfulness, vomiting, gastric ulcers, and the tremors. ${ }^{45}$ Although Hedonius' list is different from Epicurus', it brings to the discussion one of the central points in Epicurus' ethics.

The first decisively modern hedonist was Pierre Gassendi. Gassendi was an Epicurean, and in 1647, in De Vita et Mobrus Epicuri, he defended Epicurus against a line of accusations. Two years later, building on the writings of Cicero, Diogenes, Plutarch, and Lucretius, among others, Gassendi gave a systematic presentation of Epicurus' thought in Philosophiae Epicuri Syntagma.

While Aristippus and Epicurus were ethical egoists, Gassendi's variant of hedonism was universalistic. Gassendi was a Christian, and God plays an important role in the universalization. By creating Heaven and Hell, God has made sure that, ultimately, there is no conflict between self-interest and the greater good, because good deeds are rewarded and bad deeds are punished. God has also made us empathetic, so that we care for others' well-being, and more generally, he has made pleasurable the things that bring us health and painful the things that harm us. Pleasure and pain, in Gassendi's view, are instruments of God.

Gassendi had an enormous impact on the French Enlightenment. Samuel Sorbière, Jean François Sarasin, and François Bernier learned of Epicurus through Gassendi, and several of the central French philosophers in the 17th and 18th centuries - such as Helvetius, La Mettrie, Holbach, and Condorcet-were hedonists. Though they rejected Gassendi's theism, however, they stuck to his universalistic variant of the doctrine. To a large extent due to Gassendi, hedonism became a leading theory in late $17^{\text {th }}$ and early to mid $18^{\text {th }}$ century French thought.

Through Gassendi, hedonism also came to play a central role in British philosophy. In 1654 Walter Charleton translated into English the ethics section of Gassendi's Philosophiae Epicuri Syntagma, and published it as Epicurus' Morals. Later the same year he published a paraphrase of the Syntagma under the title Physiologia Epicuro-Gassendo-Charletonia.

John Locke came to know of Epicurus and Gassendi partly through Charleton, partly through Robert Boyle, who was impressed by Gassendi and who became an acquaintance of Locke when they both lived in Oxford. ${ }^{46}$ Locke,

\footnotetext{
${ }^{44}$ Martin Luther, Dr. Martin Luthers Werke, Kritische Gesamtausgabe. Briefwechsel, Verlag Hermann Böhlaus Nachfolger, Weimar, 1930-1985, p. 626.

${ }^{45}$ Erasmus, Familiar Colloquies, J. J. and P. Knapton etc., London, 1733, 884F-885A.

${ }^{46}$ Edward A. Driscoll, 'The Influence of Gassendi on Locke's Hedonism', International Philosophical Quarterly, Vol. 12, No. 1, 1972, p. 89.
} 
moreover, moved to France in 1675, where he met several of Gassendi's followers (Gassendi himself had passed away in 1655). According to Edward Driscoll, we can then observe a shift in Locke's thought away from the view that the good is adherence to God's laws toward the view that the good is pleasure. ${ }^{47}$ A decade later, in An Essay Concerning Human Understanding (1689), Locke writes:

Things then are Good or Evil, only in reference to Pleasure or Pain. That which we call Good, which is apt to cause or increase Pleasure, or diminish Pain in us; or else to procure, or preserve us the possession of any other Good, or absence of any Evil. And on the contrary we name that Evil, which is apt to produce or increase any Pain, or diminish any Pleasure in us; or else procure us any Evil, or deprive us of any Good. ${ }^{48}$

In Nouveaux Essais, Leibniz describes Locke as a defender of Gassendi. ${ }^{49}$ This is understandable, for Locke adopts Gassendi's hedonism with few or no revisions. Locke also gives God a similar role: it is God, Locke claims, who has made pleasure good and pain bad, and who continually makes sure that self-interest and the greater good are in harmony. ${ }^{50}$

Other British empiricists also held views that were close to hedonism. In Human Nature, or the Fundamental Elements of Policy, Thomas Hobbes, who was a friend of Charleton's, writes the following:

Every man, for his own part, calleth that which pleaseth, and is delight to himself, good; and that evil which displeaseth him: insomuch that while every man differeth from another in constitution, they differ also from one another concerning the common distinction of good and evil. ... And as we call good and evil the things that please and displease; so we call goodness and badness, the qualities or powers whereby they do it. ${ }^{51}$

In Scotland, Francis Hutcheson writes, in Inquiry into the Original of our Ideas of Beauty and Virtue, that:

The Pleasure in our sensible Perceptions of anykind, gives us our first Idea of natural Good, or Happiness; and then all objects

\footnotetext{
${ }^{47}$ Driscoll, p. 96.

${ }^{48}$ John Locke, An Essay Concerning Human Understanding, Cleardon Press, Oxford, 1975, Book

2 , Chapter 20, §2. Italics in the original.

${ }^{49}$ Driscoll, p. 96.

${ }^{50}$ Driscoll, p. 96.

${ }^{51}$ Thomas Hobbes, 'Human Nature, or the Fundamental Elements of Policy'. In The English Works of Thomas Hobbes, William Molesworth (ed.), Otto w. Strekcer, Darmstadt, 1966, Vol. 4, Section 7.3, p. 32 .
} 
which are apt to excite this Pleasure are call'd immediately Good. ... our sense of Pleasure is antecedent to advantage or Interest, and is the Foundation of it. We do not perceive Pleasure in objects, because it is our Interest to do so; but objects or actions are advantageous, and are pursu'd or undertaken from Interest, because we receive Pleasure from them. Our perception of Pleasure is necessary, and nothing is advantageous or naturally Good to us, but what is apt to raise Pleasure mediately, or immediately. ${ }^{52}$

David Hume, who was greatly influenced by Hutcheson, argues as follows in Enquiry Concerning the Principles of Morals:

Ask a man why he uses exercise; he will answer, because he desires to keep his health. If you then enquire, why he desires health, he will readily reply, because sickness is painful. If you push your enquiries farther, and desire a reason why he hates pain, it is impossible he can ever give any. This is an ultimate end, and is never referred to any other object.

Perhaps to your second question, why he desires health, he may also reply, that it is necessary for the exercise of his calling. If you ask, why he is anxious on that head, he will answer, because he desires to get money. If you demand Why? It is the instrument of pleasure, says he. And beyond this it is an absurdity to ask for a reason. ${ }^{53}$

In 1731, John Gay presents a novel argument for hedonism in Preliminary Dissertation concerning the Fundamental Principle of Virtue or Morality. Gay attacks what he takes to be hedonism's main contender, moral sense theory, according to which we have direct knowledge of a number of goods and evils. To attack moral sense theory, he starts out by considering the mindsets of people who mistakenly have come to believe that money is good as an end in itself. He asks:

Did not they at first perceive a great many Advantages from being posess'd of Money, and from thence conceive a Pleasure in having it, thence desire it, thence endeavor to obtain it, thence receive an actual Pleasure in obtaining it, thence desire to

\footnotetext{
${ }^{52}$ Francis Hutcheson, Inquiry into the Original of our Ideas of Beauty and Virtue, ed. Wolfgang Liedhold, 1725, Liberty Fund, Indianapolis, Ind., 2004, Treatise II, Introduction, p. 86.

${ }^{53}$ David Hume, Enquiry Concerning the Principles of Morals, Cleardon Press, Oxford, 2006, Appendix 1, 18 .
} 
preserve the Possession of it? ${ }^{54}$

Gay's point is that people who value money as an end in itself have started out by valuing it only as a means, but having done so again and again, have gotten used to the idea that money is very valuable and have stared valuing it also as an end. The same associative mechanism, Gay suggests, operates when people believe that things such as 'Knowledge, Fame \& the delight in Reading, Building, Planting, and most of the various Exercises of Life' are not only means toward pleasure, but are also ends in themselves. ${ }^{55}$ What we do in such cases, he explains, is that 'we annex Pleasure or Pain to certain Things or Actions. ${ }^{56}$ This way Gay sketches a way to defend hedonism by virtue of debunking competing theories.

Finally, hedonism found an admirer in Thomas Jefferson. We know that Jefferson owned five copies of De Rerum Naturae, ${ }^{57}$ and John Quincy Adams reported the following after a dinner with Jefferson:

Mr. Jefferson said that the Epicurean philosophy came nearest to the truth, in his opinion, of any ancient system of philosophy. He wished the work of Gassendi concerning it had been translated. It was the only accurate account of it extant. I mentioned Lucretius. He said that was only a part—only the natural philosophy. But the moral philosophy was only to be found in Gassendi. ${ }^{58}$

In a letter to William Short, Jefferson himself wrote the following:

As you say of yourself, I too am an Epicurean. I consider the genuine (not the imputed) doctrines of Epicurus as containing everything rational in moral philosophy which Greece and Rome have left us. ... I take the liberty of observing that you [William Short] are not a true disciple of our master Epicurus, in indulging the indolence to which you say you are yielding. One of his canons, you know, was that 'the indulgence which prevents a greater pleasure, or produces a greater pain, is to be avoided ${ }^{59}$

Jefferson's Epicurean sympathies might be useful to keep in mind when reading

\footnotetext{
${ }^{54}$ John Gay, 'Preliminary Dissertation Concerning the Fundamental Principle of Virtue or Morality' in W. King, An Essay on the Origin of Evil, Vol. 1, 2nd edition, edited by E. Law, London, 1732, p. xxxi.

${ }^{55}$ Ibid.

${ }^{56}$ Ibid., p. xxxiii.

${ }^{57}$ Greenblatt, p. 262.

${ }^{58}$ John Quincy Adams, 'Dinner with President Jefferson', Memoirs of John Quincy Adams, Charles Francis Adams, ed., J. B. Lippincott, Philadelphia, 1874, p. 60-61.

${ }^{59}$ Thomas Jefferson, 'Letter to William Short, from Monticello, October 31, 1819' in Merrill D. Peterson, ed., Thomas Jefferson: Writings, Library of America, New York, 1994, p. 1433. The letter also includes a reading list, assembled by Jefferson, meant to introduce William Short to Epicurus' ideas.
} 
about 'the pursuit of happiness' in the U.S. Declaration of Independence.

\section{Conclusion}

Arguably, hedonism had its heyday with the spread of utilitarianism in the $19^{\text {th }}$ Century, with Jeremy Bentham, John Mill, and Henry Sidgwick. This betterknown part of the history of hedonism lies beyond the scope of this paper. Here my aim has been to show that hedonism was an important philosophical theory also prior to Bentham - both as a theory that was positively advanced and as a theory in contrast to which other value theories (including Plato's and Aristotle's) were presented.

Considering hedonism's overall role in the history of philosophy, a topic particularly worthy of attention is hedonism's close ties to materialism and empiricism. These links make sense historically, for Democritus, Epicurus, Lucretius, and Gassendi, in addition to being hedonists, were arguably the four most central figures in the early development of materialism and empiricism. The ties also makes sense philosophically, however, since if all that exists is matter and if all our knowledge must be derived from sense experience-in Humean terms, if all ideas must be derived from impressions - then where, if not from our experiences of pleasure and pain, could our ideas of good and bad possibly come?

Though this paper provides only a sketch of hedonism's early history, I hope to have made a strong case that the fringe role that hedonism has played in the $20^{\text {th }}$ Century was an anomaly. Throughout most of the history of philosophy, hedonism has been one of the most influential value theories on offer.

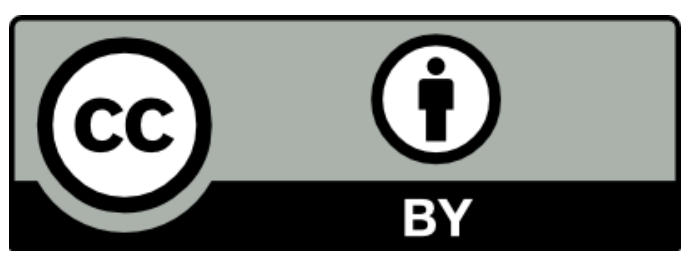

(C) Ole Martin Moen. This work is licensed under the Creative Commons Attribution 3.0 Unported International Licence. Under the terms of this licence, you are allowed to copy and redistribute this work, but must give the original author appropriate credit, provide a link to the licence, and indicate if changes were made. You may do so in a reasonanle manner, but not in any way that suggest the licensor endorses you or your use.

To view a full copy of this licence, visit: https://creativecommons.org/licenses/by/3.0/ 